Abstracta Iranica Abstracta Iranica

Revue bibliographique pour le domaine irano-aryen

Volume 31 | 2011

Comptes rendus des publications de 2008

\title{
"Composition and Continuity in Sasanian Rock Reliefs ». Iranica Antiqua 43, 2008, p. 299-358.
}

\section{Barbara Kaim}

\section{(2) OpenEdition}

1 Journals

\section{Édition électronique}

URL : http://journals.openedition.org/abstractairanica/39575

DOI : 10.4000/abstractairanica.39575

ISSN : 1961-960X

Éditeur :

CNRS (UMR 7528 Mondes iraniens et indiens), Éditions de l'IFRI

\section{Édition imprimée}

Date de publication : 15 mai 2011

ISSN : 0240-8910

\section{Référence électronique}

Barbara Kaim, « «Composition and Continuity in Sasanian Rock Reliefs ». Iranica Antiqua 43, 2008, p. 299-358. », Abstracta Iranica [En ligne], Volume 31 | 2011, document 114, mis en ligne le 15 février 2012, consulté le 05 octobre 2020. URL : http://journals.openedition.org/abstractairanica/39575 DOI : https://doi.org/10.4000/abstractairanica.39575

Ce document a été généré automatiquement le 5 octobre 2020.

Tous droits réservés 


\section{« Composition and Continuity in Sasanian Rock Reliefs ». Iranica Antiqua 43, 2008, p. 299-358.}

\section{Barbara Kaim}

1 Très intéressante analyse de la composition de huit reliefs rupestres sassanides. Cependant cette étude du mouvement de l'œil du spectateur, adoptée sans tenir compte de la hauteur à laquelle les reliefs ont été sculptés, peut susciter une certaine réticence.

INDEX

Thèmes : 3.2.3. Séleucides, Parthes et Sassanides

\section{AUTEURS}

BARBARA KAIM

Université de Varsovie 